\title{
State, market and administration of territories in the city of Rio de Janeiro
}

\section{Márcia Pereira Leite}

Instituto de Ciências Sociais, Universidade do Estado do Rio de Janeiro, Rio de Janeiro/RJ, Brasil

\begin{abstract}
This article discusses the new modality of governance of the poor in border territories of Brazilian cities, specifically in their favelas and peripheries. We analyze, based on research carried out in Rio de Janeiro, dynamics that, at first glance, could appear to be local: the disciplinarization of inhabitants, the commodification of their territories and the militarization of their lives through the Pacifying Police Units. We argue that these units' local implementation is an experiment in the production of order without democratic mediations for the management of social conflicts, which has the potential to be replicated in other territories and situations, as well as in relation to other populations under the logic of "urban militarism" (Graham).
\end{abstract}

Key words: urban militarism, favelas, peripheries, Pacifying Police Units. 


\section{Estado, mercado e gestão de territórios na cidade do Rio de Janeiro}

\section{Resumo}

$\mathrm{O}$ artigo discute a nova modalidade de governo dos pobres nos territórios de margens das cidades brasileiras, especificamente em suas favelas e periferias. Analisa, com base em pesquisas realizadas no Rio de Janeiro, dinâmicas que, a um primeiro olhar, poderiam ser supostas como locais: a disciplinarização de seus moradores, a mercantilização de seus territórios e a militarização de sua vida através das Unidades de Polícia Pacificadora. Argumenta que sua implementação local constitui um experimento de produção da ordem sem mediações democráticas para a gestão dos conflitos sociais, que tem potencial de ser replicado em outros territórios e situações, bem como em relação a outras populações sob a lógica do "militarismo urbano" (Graham).

Palavras-chave: Militarismo urbano, Favelas, Periferias, UPPs . 


\section{State, market and administration of territories in the city of Rio de Janeiro*}

\section{Márcia Pereira Leite}

The new [military] doctrine is centred around the idea that a wide spectrum of global insurgencies and ambient threats now operates across the social, technical, political, cultural and financial networks which straddle transnational scales while simultaneously penetrating the everyday spaces, sites and circulations of global cities. Such lurking threats are deemed by the latest theorist of 'asymmetric' or 'irregular' warfare to camouflage themselves within the 'clutter' of cities at home and abroad for concealment against traditional forms of military targeting (Graham 2009: 279).

This article analyzes some of the "dispositifs" of governing the poor in territories on the margins of large Brazilian cities, ${ }^{1}$ specifically their favelas - a theme that I have been pursuing in my studies for some time. My intention is to discuss some of the results of this research, and the hypotheses that stem from them. Living and studying in Rio de Janeiro, I have analyzed the relationship between the state and favelas based on some dynamics observed in the empiric research ${ }^{2}$ which, at first glance, can be understood to be local, including the new form of governing the poor through the militarization of their living territories using Unidades de Polícia Pacificadora [Police Pacification Units] (UPPs). ${ }^{3}$ I recognize, however, that this does not limit either the interest in or the relevance of their comprehension, given that these dynamics appear to not be exclusive to Rio de Janeiro. I argue that their local implementation is an experiment in the production of order, without the mediation of democratically inspired dispositifs for the administration of social conflicts. It thus involves, as Graham affirms in the epigraph, a militarization of the administration of life and of urban conflicts based on a military rhetoric and practices that are increasingly considered to be central (and necessary) to the government of cities and urban safety (Foucault 2004a).

My argument will be developed through an analysis of how the management of favela territories is processed today in Rio de Janeiro with the UPPs, discussing the commodification of the city's territories, the disciplinarization of the residents and the militarization of their life by the UPPs.

\footnotetext{
1 Margins are understood here using the analytical perspective developed by Das and Poole (2004) as spaces, populations and practices that are the object of a specific state administration, which, combining legal-illegal, licit-illicit, legible-illegible, are permanently redefined in an active coproduction of the state and its "margins". The notion of government of the poor is supported by Foucault's analysis of governmentality as a form of exercising power "the main target of which is the population, the most important form of knowledge is political economy, its essential technical instrument is the dispositifs of security" (2010: 303), involving the preeminence of sovereignty and of discipline for modeling conduct, and therefore, not only the governing of others, but also the governing of oneself. This highlights, in the case of Rio de Janeiro, the territorial inscription of this form of exercising power in the locations of residence of the poor, which are not restricted to the exercise of state power.

2 I refer to the studies "Territórios da pobreza, segregação e políticas públicas: novas feições da sociabilidade em favelas" (PQ/CNPq and PROCIENCIA/ FAPERJ/UERJ) and "Territorialidade, Estado e Mercado: margens e regimes territoriais na cidade do Rio de Janeiro" (FAPERJ) and to the collective studies "Virtudes e Limites das UPPs: uma avaliação socioantropologica" (FAPERJ, 2010) and "Juventudes em comunidades com Unidades de Polícia Pacificadora: perfil, expectativas e projetos em suas comunidades" (FLACSO, 2011), conducted by CEVIS/IESP/UERJ and coordinated by Machado da Silva.

3 UPPs are permanent police posts implanted in favelas with a squad of state military police who according to the Secretariat of Public Safety of Rio de Janeiro State (SSP), are trained to operate according to the dictates of "proximity policing". For more information about the proposal and mode of operation of the UPPs, see: Leite $(2012,2015)$ and the dossier organized by Machado da Silva and Leite $(2014,2015)$, among others. Note that Rio de Janeiro has, according to the 2010 census, 1,071 favelas. Until now 37 UPPs have been implanted in favelas in the city of Rio de Janeiro. More than half were placed in the "noble" area of the city and or near the sports facilities constructed or remodeled for the "big events". According to the SPP, each UPP would produce effects of "pacification around the group of favelas in which it is implanted. Thus, 257 localities would be reached by the dispositif (without considering the UPP Mangueirinha, in Baixada Fluminense, in the periphery of Rio). The expansion to the Baixada Fluminense region, because of local requests, indicates the potential for the replication of this measure. About these requests for UPPs, see Miagusko (2016).
} 
Before enunciating it, I explain the reference to the city's favelas as a periphery. The favelas, locations that were originally precarious in terms of housing and urban equipment and services, were shaped as territories that were occupied as residential options, by a population that because of its labor and salary conditions was not able to buy or rent residences in other locations, or to meet the costs of the daily travel to their workplaces. ${ }^{4}$ Despite their great heterogeneity (Valladares 2005), the favelas were always the object of a specific state administration in terms of urban infrastructure and public policies, which were never effectively integrated to the rest of the city. From this perspective, they were (and still are) a periphery of the city, as one of the margins of the state of Rio de Janeiro.

The article is organized in four sections. In the first, I present the policy for implementation of the UPPs in the Rio de Janeiro favelas as a central part of the re-structuring of Rio de Janeiro as a "city of business" (Harvey 2005, Compans 1999, Ribeiro and Santos Jr. 2013) which would reduce urban violence in the period of the preparation of the city to host the "big events", a cycle that ended with the 2016 Olympic games and Paralympics. ${ }^{5}$ In the second, I examine some dispositifs triggered by the UPPs in these territories and in relation to their population. I argue that the sense of this government policy is not limited to guaranteeing effective action of the militarized security forces ${ }^{6}$ in territories considered to be hotbeds of violent crime, by seeking to eliminate or limit illicit drug trafficking. My aim is to demonstrate that what is experimented is a modality of government of the poor in the city that has a dual meaning. On one hand, it reconfigures the favelas as new business territories for the market, in a sense indicated by Harvey (2005), i.e., as spaces for expansion of urban accumulation by implementing public policies that are closely tied to private interests. On the other, it deals with the demands for social and urban integration of their residents by offering them insertion in the market through entrepreneurship. In the third section I discuss how this form of government is realized in the favelas with UPPs. I focus on another face of disciplinarization of residents: which is processed through the militarization of life in the favelas, which allows the state to reduce the social conflicts located there, always by maintaining a recourse to dispositifs from the field of sovereignty to "let die" (Foucault 2004a) those considered to be ungovernable. In the conclusion, I suggest that this modality of government of the poor in carioca ${ }^{7 *}$ favelas has the potential to be replicated in other situations and for populations in other cities, evidently with adjustments in the specific arrangements of the security technologies (Collier 2009). I argue that this experiment in the production of order with UPPs is found in the circuit of diffusion of "urban militarism" in the terms used by Graham (2009), to allow the state and its partners to reduce social conflicts, emphasizing "market imperatives" instead of the democratic conquests of the expansion of citizenship.

\footnotetext{
4 Later, the city produced other peripheries, occupied with subdivisions and housing projects, incorporating into their urban dynamic neighboring cities that are now part of the Rio de Janeiro Metropolitan Region and subordinating them economically and socially, especially the Baixada Fluminense (Freire 2016). But the favelas, as the city's closest "periphery", continue to grow in number, population and total residences. The city is now expanding through various processes. Of these I highlight a new movement of peripheralization of poverty through housing projects built in the federal Minha Casa Minha Vida [My Home My Life] low income housing program, usually in areas that lack urban infrastructure (Conceição 2016).

5 In addition to the traditional events in the city like Carnival, New Years Eve in Copacabana and Rock in Rio, the cycle of "big events" involved: the Environmental Conference Rio + 20 in 2012, the Catholic Church's World Youth Day in 2013, the Confederations Cup in 2013, the 2014 World Cup, the World Military Games in 2015 and the 2016 Olympics and Paralympics.

6 In Brazil, public safety in the cities is the responsibility of state governments, and is operated by militarized forces. The so-called Military Police (PM) is responsible for preventive and ostensive policing and the maintenance of public order (and is considered a reserve of the armed forces). The enactment of judicial and investigative attributions are the responsibility of the Civil Police, or, in the case of federal issues, the Federal Police. In the specific realm of municipalities, there is the Municipal Guard, which uses non-lethal weapons, and which is responsible for protecting the assets of the cities and that can be agencied to collaborate towards public safety. The Armed Forces can also be used to maintain public safety (and frequently are).

7 "Carioca" is the adjective for a person or thing from Rio de Janeiro.
} 


\section{The experiment with the UPPs in the carioca favelas}

There was great celebration in Rio de Janeiro in 2009 when the International Olympic Committee (IOC) chose the city to host the 2016 Olympics. Residents, and business and government leaders all celebrated, not only because of a passion for sports, but because they believed that at a good moment in the country's economy the games would open a "window of opportunity" for the former federal capital to be re-organized as a "city of business" (Miagusko 2012) and thus regain its former political and economic dynamism. There was, however, a problem, which was accompanied by promises by government leaders that it would be resolved, made to the IOC and to Brazilian and international investors articulated around this project; the city was considered very violent. This had already led to a noticeable decrease in the domestic and international flow of tourists, as well as an economic deterioration of the city. ${ }^{8}$ This violence was related to dynamics of illegal drug trafficking, whose points of sale were implanted years earlier in the favelas and peripheries (Leite 2012, 2015; Machado da Silva 2008). Thus, one of the central elements in the preparation of Rio as the "Olympic city" was to focus on these territories, to reduce the violence that overflowed from them to the rest of the city.

In December 2008, in the wake of the consequences of an intensification of criminal and state violence in one of the largest groups of favelas in the city, ${ }^{9}$ the Rio de Janeiro state government gradually forged what came to be known as a "pacification" policy for the favelas. Beginning with the occupation of the favela Santa Marta (which is small and nestled close to a prestigious region of the city) by the Military Police, government officials announced that they would launch there a dispositif of "proximity policing", with special forces that would remain permanently in the location: and would later be called Police Pacification Units (UPPs) (Leite 2015, 2012; Cano et al. 2012; Machado da Silva and Leite 2014, 2015, and others). The UPPs would recuperate the state's sovereignty in these locations, expelling the drug traffickers who had military command of the territories and over the lives and choices of the residents. Thus, they would bring peace to the favelas and to the city. This was a moment when the policy for the "pacification" of the favelas had great public approval, both in the media, and among most residents in the city, social scientists and parliamentarians, who all accepted the idea that the favelas with UPPs had in fact been "pacified" by the permanent presence of a militarized police force.

Nearly 2 years later, a new announcement was made: the creation of the Social UPP ${ }^{10}$ which would recover the state's "social debt" with the population living there, implanting in the territory the basic urban facilities that residents had long requested as their rights as citizens. It would thus be necessary for a state military force that was competitive with the criminal forces to occupy these territories, to simultaneously provide the residents new living choices, and for the state to exercise its sovereignty, implementing its effective presence through its specific institutions and through concessions of public services that would

\footnotetext{
8 Cesar Maia, mayor of the city for 3 mandates (1993/97, 2001/05, 2005/09), affirmed that Rio faced a "deep urban crisis", related to deindustrialization and the loss of the city's tourist potential given the representation of Rio de Janeiro as "extremely violent" and the lack of investments in its most valuable areas. His government's strategic planning sought to revert these factors and project the "reconstruction" of the city based by defining the potential of each region for the market, sparked by investments in ecotourism, leisure and culture (Espíndola 2009). They thus broke with the conception and practices of a more "horizontal" intervention in the city, in terms of implantation of urban equipment and services, following the principle of the universality of the rights of citizenship.

9 I refer to the Chacina do Pan (The Pan Massacre, names during the Pan American Games, held in the city in 2007), the product of a violent actions by militarized police forces in the Complexo do Alemão region, which according to the literature and Coronel Robson Rodrigues (then General Commander of the UPPs, who was interviewed by Machado da Silva and I in 2011) was the "start for the SSP to begin to think of what and how to do in the favelas to contain violence from drug trafficking". About the repercussions of the Chacina do Pan in the Brazilian and international press and its relationship with the "invention of the UPPs", see Palermo (2011).

10 Program formulated with the objective to articulate the interventions of public agencies in the locations with UPPs and promote partnerships between the municipal, state and federal governments, the private sector and NGOs for the urban integration of these territories and their residents. About their mode of operation and the progressive shift in direction to a priority focus on entrepreneurship, see Leite (2015) and Carvalho (2014).
} 
realize the constantly promised urban integration of the favelas. In this process, the state would construct its legitimacy in the "pacified" territories, to the degree that it was undoing what it designated with war metaphors, ${ }^{11}$ as the connections and loyalties of the residents to the drug traffickers.

Even if the residents of the "pacified" favelas had many complaints about the action of the military police (the residents commonly affirmed that the UPP commanders became the new donos do morro ${ }^{12}$ [boss of the hill], in an allusion to the modes of operation of drug traffickers in these locations), they approved the fact that for the first time in decades the permanent policing in these locations had noticeably decreased the gunfire and the homicides, both those produced by confrontations between different gangs for the control of territories, as well as those produced by the police in their incursions into the favelas under the logic of the metaphor of war. They also valued the possibility of being able to travel through the favelas, once the borders of armed territorial commands were broken down. And they breathed with relief because they could finally conduct their daily routines with a modicum of safety (Machado da Silva 2008). But they also had criticisms, and harsh ones. Police brutality continued: including physical searches of residents and frequent aggressions, which demonstrated that the police continued to see and treat the residents as enemies, supposing that they are in some way complicit with the criminals. "If we do not accept, they complain, insult us, slap us in the face, accuse us of contempt" ${ }^{\prime \prime 13}$, as residents complain. Meanwhile, they say that the police, "are complicit with the bandits. The "boca" [drug-selling points] $]^{14}$ came back to the same place. Right where it was before...You know what the police do? Nothing! They go down the next street, but they don't go there! The payoffs were made." And, little by little, shootings and homicides decreased, returned and increased, ${ }^{15}$ given that the state wound up conciliating with the drug traffickers and reconsidering its initial objective (to eliminate trafficking in these territories and to arrest its operators), limiting it to "no ostensive use of arms in the locations".

I would like to highlight three combined processes. On one hand, the official pronouncements of the SSP, which is responsible for the administration of public safety and of the UPP experiment, affirm that the main objective of the pacification policy had always strictly been the "elimination of the rifle". This overtook the previous focus on the "return of state sovereignty over these territories", and in a certain sense rewrote the history (Leite 2015). On the other hand, by focusing its policy on "eliminating the rifle" the state fundamentally came to seek, through the UPPs, to reduce the violence that overflowed from the favelas to the city and compromised its image. ${ }^{16}$ Finally, this shift in meaning of the policy for the "pacification" of the favelas represented a new orientation (even if an informal one) from the SSP to the police assigned to the UPPs. The SSP implicitly accepted the return of the usual practices of the military police in the territories in their contacts with violent crime to seek compliance to the new objective of the UPPs: crime

11 I designate as a war metaphor the representation of the city as being torn by conflicts and contradictions between the favelas (typified as territories of violence and the illegalities related to them) and the rest of the city (represented as the space of state order and citizenship), which guided, since the 1980s (and until today in the favelas without UPPs), the state policies and practices in the field of public safety. About this theme see Leite (2012).

12 I use italics for the native categories. I use quotes for the categories used by the media and by the police and other operators from the state.

13 Cf. Article 331 of the Penal Code that refers to "contempt towards a public employee in the exercise of his function or because of it". The penalty is 6 months to 2 years in jail or a fine. On 15/12/2016, the Supremo Tribunal de Justiça decriminalized “contempt". The Brazilian penal code, however, established the crime of disobedience ("to disobey the legal order of a public employee", article 330), which carries a penalty of 15 days to 6 months of detention or a fine and continues as a dispositif of "exception".

Cfr. $\{$ http://www1.folha.uol.com.br/cotidiano/2016/12/1842236-descriminalizacao-do-desacato-e-decisao-historica-dizem-especialistas.shtml\}, accessed in December 2016.

14 Retail point of sale of drugs.

15 On the increase of the lethalness of police in these locations, and in general in the favelas and peripheries of Rio de Janeiro in the period, see: "Onde a polícia mata: homicídios praticados por policiais militares no estado do Rio de Janeiro", prepared by the NGO Justiça Global based on official data from the Instituto de Segurança Pública. Source: https://medium.com/@justicaglobal/onde-a-pol\%C $3 \%$ ADcia-mata-homic\%C $3 \%$ ADdios-praticados-por-policiaismilitares-no-estado-do-rio-de-janeiro-9797c1b8041a\#.rr5mmagdt, accessed in November 2016.

16 I am considering the distance between the initial formulation of the UPP project as a "proximity police" that would bring safety to the residents of the "pacified" territories and its effective implementation in these territories, which can be grasped by what I designated above as the complaints of residents in relation to the UPPs. 
could continue, as long as it was "pacified": without territorial disputes and without confrontations with the police. And, as all the studies show (Machado da Silva and Leite 2014, 2015, among others), the illegal activity (illicit drug dealing), was once again conducted openly in the favelas with a UPP. In the same way, the military police returned to its usual practices that combined conviviality and collusion with violent crime, thus participating in the illegal market generated by its operators through the negotiation of what Misse (2011) designates as "political merchandise": charging bribes (arrego) from traffickers to not conduct their official activity in these places/situations (patrols of points of sale, arrests, confiscation of guns and merchandise, etc.) or, even, to protect them, through various strategies, from rival gangs in disputes over sales territories. These state practices in the Rio de Janeiro favelas, the "political merchandise" negotiated by the operators of the state (the PMs), participate in an illegal market that is protected and leveraged by the recourse available to the police, by delegation of the state, to act in its name and under the cover of its objectives and essential functions. Its exchange value depends on the correlation of forces between the rival groups of traffickers and the specific context of formulation/implementation of public safety policies that can expand or reduce the market value of the forms of protection. From this perspective, it is important to highlight a final point. As demonstrated by the implicit permission of the SSP for the return of the common state practices of their operators in the "pacified" territories, far from representing a disfunctionality of the state, these practices are one of the common modes of state management of these territories as margins.

Therefore, in the year prior to the realization of the Olympics, the territorial command of the drug dealers had already been mostly recovered in the "pacified" favelas. Little by little, disputes returned between rival gangs for the conquest of the most profitable locations for illegal drug sales, renewing the lack of safety of the residents and of the "city". People began to speak of the "crisis of the UPPs": residents, media and the operators of public safety themselves debated what had gone wrong. The Secretary of Public Safety of Rio de Janeiro, José Mariano Beltrame, attributed the crisis to the lack of public investments in the "pacification" policy; to a lack of sufficient and properly trained forces, outdated military equipment, and to the fact that the police rank and file was discontent with the salary policy. After the Olympics, he asked to stepped down. The governor, lamenting Beltrame's departure and praising him for his action, explained that the lack of public investments was temporary and due to the financial crisis that the state was experiencing. But a certain consensus was solidified that the UPPs had already fulfilled their cycle - linked to the "big events" - and would be terminated, because they had proved to be ineffective.

But did the UPPs actually fail? This appears to me to be a central question to discuss in this article. After all, if the main objective of this government policy was to guarantee an effective action of the militarized security forces in the territories considered to be spaces of violent crime, seeking to eliminate, or even only to reduce illicit drug dealing, it would be necessary to recognize their failure. But from another perspective it appears to me that the experiment with the UPPs was successful in some fields. This is suggested by three important facts. I can highlight, on one hand, the proposal being deliberated in the federal Chamber of Deputies to transform the implementation of the UPPs into a state policy, for 25 years, and to nationalize it, implementing them in other territories of the country that face violence and crime similar to that found in Rio de Janeiro ${ }^{17}$. Another is the direct involvement of various Brazilian and foreign companies in the experiment, with private financing. One was EBX, of Eike Batista (who was then Brazil's richest man and the 8th in the world according to Forbes magazine), Coca Cola, Souza Cruz, Bradesco Seguros, and others, as well as partnerships with the Brazilian Confederation of Football, the Federation of Industries of Rio de Janeiro state and the Federation of Commerce, Goods, Services and Tourism of Rio de Janeiro

17 PL 370/2011, presented by federal deputy Alessandro Molon, which continues to be debated in the Chamber of Deputies with the substitute bill n. 1 presented by Deputy Luiz Couto to the Commission of the Constitution and Justice and Citizenship, on 26/06/2017. 
State (Gomes 2016). ${ }^{18}$ The third is that the UPP policy stimulated the production of a technology of power, which was considered in Brazil and abroad to be effective for the government of territories and or poor populations and for reducing localized social conflicts.

\section{The successes of the UPPs in the commodification of the "pacified" territories}

State Secretary of Safety, José Mariano Beltrame, delivered the "Tool Kit" today at the auditorium of the Secretariat of Safety, the "Police Pacification Unit - UPP: from the origin of the program for a pacification policy", with the entire history of the policy of pacification materialized in the UPPs. The manual, accompanied by three didactic books, a book with the history of the UPPs and a CD was received by the Minister of Justice of El Salvador, Benito Lara. The ceremony included representatives of the Brazilian, Salvadoran and U.S. governments, whose U.S. Agency for International Development [USAID] provided financial support for the drafting of the manual. "Formally, El Salvador was the first country that requested this exchange. Informally, we had visits from many other countries, internal meetings to learn about the operation of the UPP, like that with Panama and the United States (...) Beltrame said. (...) The work began to be conducted a year and a half ago, in general lines, it has very important supports, which can help any other country that has a reality similar to our state. The police forces must be protagonists to guarantee citizenship. With the UPPs, the police assure the arrival of mechanisms that keep youth and people from the possibility of practices of urban violence (...). In Latin America, we must revert this situation, review the causes that lead to violence", he concluded. (http:/I www.rj.gov.br/web/seseg/exibeconteudo?article-id=2512407, accessed in November 2016, emphasis added).

I propose, in this section, another reading of the "crisis of the UPPs" which emphasizes what I understand to be central focuses of the policy for "pacification" of the favelas. The first focus is related to what I have been denominating the cycle of "big events" in the city and to the circuits of production of a governmentality focused on safety that they are associated to. From this angle, it should be considered that from 2008 to 2016 (from the inauguration of the first UPP until the announcement of their "crisis"), this dispositif demonstrated it was effective because it made viable the city's preparation for the events. Thus, if the UPPs did not effectively decrease violence over the entire period, they at least led to a noticeable drop, according to public perception of violence (cf. Machado da Silva and Leite 2014, 2015, among others), in part to the degree to which they were instrumentalized as proof of the "pacification" of the favelas and of the city by the state and municipal governments in their public pronouncements and in their agencyings to attract investors and tourists. ${ }^{19}$ The international circulation of this experiment, through in loco visits of government officials and leaders from other countries, ${ }^{20}$ the financial support offered by USAID for the production of this "technology of pacification" and its insertion in the international circuit of "urban militarism" (elements mentioned and emphasized on the official site of the UPPs, according to the citation in epigraph) appear to leave no doubts about the issue.

\footnotetext{
18 Silvia Ramos, then Municipal Undersecretary of Integrated Actions in the Territory, acting in the Social UPP, considered this initiative "a capitalist investment in the future, but with a social sensibility", affirming: "They want to conquer the [lower] classes C, D and E. The favelas have thus become a socially attractive market." And emphasized that one of the first actions of the police to expel the armed dealers was to destroy the clandestine electrical and cable TV hookups. "Empresas ajudam a financiar a pacificação", em http://www1.folha.uol.com.br/fsp/cotidian/ff2811201040.htm, acesso em outubro de 2016. 19 I highlight the practice of guided visits by police from the UPPs in these locations (with scheduling available on the official website of the UPPs) and the celebration of the good moment by government officials and business leaders. See, for example, the article by the Brazilian Association of Event Companies "Rio se consolida como capital de grandes eventos", de 25/9/2011, in http://www.abeoc.org.br/2011/og/rio-se-consolida-como-capital-de-grandes-eventos/, consulted in November 2016.

20 For example, the visit of U.S. President Barack Obama to the neighborhood Cidade de Deus and of the Minister of Justice of the United Kingdom, Chris Graylling, to Santa Marta, and of former NYC Mayor Michael Bloomberg and of actor Harrison Ford to Babilônia.
} 
From this perspective, what I call the "international circuit of a governmentality focused on safety", must be better clarified. I refer to its presence in two experiences with "urban militarism" that were appropriated in the formulation and implementation of the UPP experiment: the militarization of the living territories of the poor in Colombia, studied in loco by Rio de Janeiro government officials ${ }^{21}$ and the experience of "stabilization" of Haiti, begun in 2004 and that lasted more than 10 years, defined by the United Nations and conducted by the Brazilian army to assure "order and peace" in that country. ${ }^{22}$ In the case of Colombia, Meza (2015) affirms that a geopolitics of drugs was substituted by a geopolitics of safety, which was articulated in a "transversal space" between the sovereignty of the states and international cooperation. From this perspective, in the two cases, what was in question was the diffusion and the appropriation (by local and national governments) of the "good practices" ${ }^{23}$ that articulated military and security strategies for the administration of territories and urban populations. As Roy (2012) and Ferguson and Gupta (2002) found, this process involves a transnational circulation of ideas and projects among government officials, researchers and multilateral agencies, through think tanks that produce and reproduce a transnational governmentality.

And the circuit is completed, at least for now, with an agencying in a reverse direction: the support and diffusion of the UPP experiment by USAID, as part of its operations in the field of "citizen safety" in relation to Latin America and the Caribbean:

USAID/Brazil and the State of Rio de Janeiro Security Secretariat formed a trilateral cooperation partnership to increase citizen security in third countries. This partnership draws upon the Secretariat's expertise, experience and proven models for transforming violence-prone neighborhoods without public services into peaceful communities with schools, healthcare, and job opportunities (https:/|www.usaid.gov/brazil/our-work/trilateralcooperation, accessed in December 2016).

My hypothesis in relation to this aspect is that this support is shaped, in the circuit that we are examining, as a part of what Meza analyzes as a strategy of counterinsurgent government war. It has been approved by the U.S. State Department based on experiences in Colombia and conflicts in Central Asia. This "Territorial Consolidation" has two key concepts:

First: reconstruction of the political, socioeconomic and physical infrastructure of a territory or country that has been degraded, compromised or destroyed (as in a war offensive), seeking to establish the bases for longlasting development. (...) Second; stabilization, by means of which the subjacent tensions, which threatened a resurgence of situations of violence and a break from law and order, be addressed and decreased, to the degree that the efforts made create conditions for successful development (2015: 374).

Returning to the central argument, I would like to present what I consider the second central focus of the "Pacification of favelas" that resulted from my studies. In them, I took seriously a recurring statement, among many with the same meaning, made by residents who I accompanied: "behind the military police

\footnotetext{
21 The circulation of Brazilian government officials to find in Colombia elements for the configuration of the "favela pacification" policy was broadly reported in the media. For example, in http://extra.globo.com/noticias/rio/em-visita-colombia-cabral-conhece-programas-de-seguranca-734145.html, accessed in November 2016.

22 The experiment conducted by Brazil - to keep the "peace" by guaranteeing public order favorable to the market (especially in relation to the increased precariousness of labor in Haiti), at the same time that it sought to qualify for a seat on the UN Security Council - was highlighted to me in an oral communication by Rodrigo Calvet.

23 This involves actions and policies defined as effective for the solution of social problems that receive this qualification in these international circuits (Bessen 2016). Lugones (2016), in oral communication at the V Congreso Latinoamericano de Antropología (Colômbia, 2017) about "good practices" in Córdoba, Argentina, highlighted how their configuration as being paradigmatic allows this governing technology to be "replicated and replicable" in other contexts and situations..
} 
and their "caveirão", ${ }_{24}$ right behind, comes the cable TV truck...". What the residents perceive, describe and tell me appears to be very clear. One of the focuses, perhaps the central one, of the militarization of their living territories was to allow the market to "invade" the favelas. This does not involve a first opening of the favelas to the market, because favela residents were always integrated to labor markets and capitalist consumption, and a variety of activities were conducted and goods were sold as part of the local economy. I think that what the dispositif of militarization of the favelas allowed (and efficiently, at least contextually) was, their reconfiguration as new territories for business for the market, as a space for the expansion of market frontiers through new processes of urban accumulation: (a) stimulating a more aggressive strategy for conquest of the consumer market in the favelas by financial, real estate and commercial companies and service providers who located there; (b) producing competition with the activities conducted there that strongly influence the local economy; and (c) through the UPPs and their promise to make the "pacified" favelas "safe territories", by providing the conditions to make possible a more effective commodification of space, of housing and cultural initiatives and of the generation of income of their residents. ${ }^{25}$

The first strategy, defined according to the guidelines of USAID for the field of "citizen security" was announced by the operators of the experiment, as can be seen in its official website:

The pacification still has an essential role in the social and economic development of the communities, because it stimulates the entrance of public services, infrastructure, social, sporting and cultural projects, private investments and opportunities. (Source: http://www.upprj.com/index.php/o_que_e_upp, accessed in December 2016.)

This strategy has been agencied by the municipal government of Rio de Janeiro, a partner in the UPP experiment, with eyes on the Brazilian and international market, in the circuit that promotes its "good practices":

The potential for consumption in the favelas has been awakening the attention of private business for a few years. In Rocinha, (...) bank branches, lottery sales posts (bill-paying agencies) and retail commerce have already bet on the success of their business since the 199os. With Brazil's economic growth, the improved distribution of income and the entrance of the poor population to the middle class, the rhythm increased. Twelve million people live in the Brazilian favelas and have a total purchasing power of $\mathrm{R} \$ 56$ billion in goods and services, according to a survey conducted by the Data Popular and Data Favela institutes. This is higher than the gross national product of countries such as Bolivia and Paraguay." "“Nas comunidades pacificadas, o mercado integra", Development Made in Rio, publication of PCRJ, Ano 1, edição 4, 12 de 2014, pp. 37-41, available at (http:/| www.rio.rj.gov.br/documents/91329/a5475572-bd4o-439b-aggf-ocba8gcb973b, consulted in November 2016.)

The second strategy was felt and expressed by many of the residents I accompanied in my studies: Life is very difficult here. Everything is very expensive. Rent went up, the prices of everything in the [local] stores. And electricity? They promised a social rate [for electricity now provided by the Light utility company which has substituted former clandestine connections], but it is more expensive than on the "asphalt" [the formal neighborhoods]. And it doesn't work well. Or the water, there is no water at least two or three times a week, every week...

\footnotetext{
24 Armored military combat vehicle, used by the elite segment of the military police, the Special Police Operations Battalion (BOPE), in its incursions into carioca favelas, which has the BOPE symbol (a skull and cross bones [caveira in Portuguese] with a dagger lodged into it with two golden pistols).

25 I refer to the opening of a new territorial frontier for the market which combines with and stimulates the viability of the project to re-structure Rio de Janeiro as the "city of business", taking advantage of the context of the "big events".
} 
You can't do anything here. My neighbor had already bought all the material to build a second floor above his house. His daughter got married. He was saving money and bought bricks, cement, everything. When the store came to deliver it, the people from SMH [the municipal housing department] prohibited the construction. No you can't [build], not any more...”

In these statements, as in many others, my interlocutors report various aspects of this commodification of life in favelas made viable by the promise that the UPPs would make the territory "safe" for business. Cable TV companies, shops, tourism and entertainment, real estate, finance, event sponsors and other companies occupy space in the local economy by offering their services at market prices, at the same time as the state began an offensive to regularize addresses, ${ }^{26}$ residences, commercial activities and electricity consumption. The case of electricity is a good example. In Rio de Janeiro, the Light electrical utility has the monopoly on supply of this good that had always been a dispositif of local accumulation in the favelas, through the common practice of illegal connections to the power grid (known as gatos). With the compulsory regularization of electrical connections, there was a strong reaction and protests from residents, particularly because of the high rates, which were disregarded by the company and the state. The hookups were also criminalized, through the suspension of supply without an examination of the complaints, fines and punishment, and propaganda that presented the failure to regularize electrical connections as uncivilized behavior of those who do not know how (and cannot be) citizens as demonstrated by Loretti (2016), Ost and Fleury (2013) and Cunha and Mello (2011) in discussing the proposal for urban and social integration through consumption via UPPs.

The regularization of commercial activities and services in the favelas, presented as part of the agencyings to produce "successful development" in these territories is another point of the process examined. The agencyings of the state in this sense have strong support from the Brazilian Support Service for Micro and Small Companies, (SEBRAE) which migrated its operations in the field of economic solidarity (support for initiatives to generate work and income) to entrepreneurship (Lima 2008). SEBRAE promotes: (a) debureaucratization of accreditation; (b) reduction of taxes (above all for individual micro-entrepreneurs with revenues up to $\mathrm{R} \$ 60.000,00$ per year [approximately US\$20,000] and at most one contracted employee receiving a minimum wage or the base salary for the professional category); (c) training courses (to identify local potential and vocations and competent business management); and (d) access to microcredit. ${ }^{27}$ Its agenda of activities in these localities is intense, offering courses in entrepreneurship that promise that they can create business opportunities for the population, with generation of income and employment, particularly for:

The electrician, the seamstress, the barber, the manicurist, the builder, the artisan, the teacher who gives music classes at home, that is, independent and mobile [workers] who normally do not pay taxes, but also do not have social security benefits or the same benefits as those who have formal employment. To work in a regularized form has advantages. According to Sebrae, to be classified as an individual micro-entrepreneur is an opportunity for those who work on their own to conquer rights and formalize a small business without bureaucracy and free of charge." ("Quer regularizar seu negócio? A gente ensina”, Texto de divulgação do

\footnotetext{
26 I cannot focus on this aspect, but it involves a strategy to map and collect information about the favelas and their population (via Light and complementary to surveys conducted by the UPP Social) in the field of biopolitics. See Carvalho (2014) and Cunha and Mello (2011).

27 "The first big difficulty for the entrepreneur is access to credit. For this reason, the UPP Entrepreneur Fund was created within the UPP program, administered by AgeRio, the state finance agency, linked to the State Secretariat for Economic Development, Energy, Industry and Services (SEDEIS). They are granted financing of between $\mathrm{R} \$ 300$ and $\mathrm{R} \$ 15$ thousand, with interest of $0,25 \%$ (3\% per year) and 24 months to payback the loan with a grace period up to three months". Source: http://www.rio.rj.gov.br/documents/91329/a5475572-bd40-439b-aggf-ocba8gcb973b, accessed December 2016.
} 
SEBRAE, published in October 2019. Source: http://noticias.r7.com/economia/noticias/quer-regularizar-o-seunegocio-a-gente-ensina-20091009.html, accessed in November 2016)28.

Many residents adhere to this proposal, especially in the fields of tourism, food services and crafts, stimulated by the state or by NGOs with special projects, ${ }^{29}$ in this case, especially in the field of culture (De Tommazi, to be published). Later many complained that they never gained access to microcredit and that the courses promised did not arrive. Others discarded it immediately, above all the owners of small informal businesses in the favelas of food and traditional services. They argued that almost nothing was left over at the end of the month, how could they have permanent and regularized employees? Demanding differentiated treatment, as favela residents who had always been abandoned by the state, they pondered: "I don't even know if I am going to be able to pay the bills this month. So how can I pay taxes and a full salary to the kid who I call to help when business is good?”.

No less important, in this process, were other opportunities to transform these territories into commodities, which were strongly stimulated by the state. ${ }^{30}$ These include: the organization of events and tourism in the favelas by companies and the proliferation of hostels and posadas in homes purchased by people from outside the location, using the favela as a trademark, to bestow extra charm to the activities (Freire-Medeiros 2013). In this case, I do not refer to all the "pacified" favelas, but to those that have some distinction that can be appropriated as a value by the market: the surrounding nature (overlooking the ocean) as found in Rocinha, Vidigal, Cantagalo, Pavão-Pavãozinho, Chapéu Mangueira and Babilônia; a specific cultural manifestation (as found at Morro da Serrinha, the traditional home of jongo - a dance of African origin cultivated by black slaves and their descendants); or even the theme of sustainable development (as found at Chapéu Mangueira and Babilônia, which are polarized by an environmental preserve).

At first, many of the residents hoped to be treated by the state according to the official discourse and justification: "the UPPs will recover the social debt owed to the favelas". For this reason they hoped not only for the implementation of urban facilities and the goods of citizenship in the "pacified" favelas that had long been requested, but also expected discounted social rates for regularized electricity, differentiated rates for (agile) concession of microcredit, effective stimulus and support from SEBRAE so that they can administer their survival and better integrate to the labor and consumer markets. What the "market" visualized and presented as a "window of opportunities" was appropriated with a certain mistrust, but also with hope expressed in a recurring statement: "who knows, perhaps this time it will work?" Another party (the leaders of community movements and base organizations), who participate actively in the meetings organized by the Social UPP and other forums, at which they promised to bring urban facilities and public services to the locations, criticized the substitution of the repertoire of citizenship for that of entrepreneurship. Nevertheless, they sought to adjust their individual and collective trajectories to the "political time of the city" (Telles and Cabanes 2006). From this perspective, whether in the territory, or in relation to the state and para-state forums in which they are engaged, trying to make these opportunities viable, they respond to the agencyings of the state and its partners by getting involved in surveys and

28 The profile of the entrepreneurs in the "pacified" favelas is presented by the Rio de Janeiro municipal government: $94 \%$ act independently; have an average age of 43; low schooling (average of 7 years of studies); most are women; work in commerce or services. Source: http://www.rio.rj.gov.br/documents/91329/ a5475572-bd40-439b-a9gf-ocba89cb973b, accessed in December 2016.

29 NGOs that work in Brazil with poor and favela youth with social projects, of a para-state nature and whose scope, "keeps this segment from crime", criminalize this youth without offering them an effective insertion in the labor market. See Rocha (2013).

30 The passage elucidates the agencying highlighted: "If previously it was money from trafficking and the funk dances that drove the local market, today it is the rise of low income consumers. (...) Because it is an 'exotic' environment for many Europeans...the favelas come to be part of their tourist itineraries when they come to Rio de Janeiro. This is good for the community and good for the microentrepreneurs who invest in the businesses. To know more about the theme and guidance for your business, new ideas and how to obtain investments, contact SEBRAE (...)." "Pequenos negócios precisam se reinventar nas comunidades pacificadas". Source: http://www.sebrae.com.br/sites/PortalSebrae/artigos/pequenos-negocios-precisam-se-reinventar-nas-comunidades-pac ificadas,4d5ddb1717fb6410VgnVCM10oooo3b74010aRCRD, accessed December 2016. 
developing projects, which did not have the expected responses (Rocha 2014). Most of the residents of the "pacified" favelas who I have been accompanying, say that the current situation express total disillusion with the promises of urban and social integration of the favela residents with the UPPs.

In parallel, real estate speculation advanced in the favelas, whose counter point has been the significant increase in the removal of its residents (Azevedo and Faulhaber 2015, Magalhães 2013). These evictions are justified in a number of way. They may be presented as a form of "dedensification" of these areas to allow for effective urban intervention for the remaining residents ${ }^{31}$ (as in the case of the municipal housing program known as Morar Carioca). Or they are explicitly operated as expansions of the frontiers of the real estate market unlocking territorial assets that until recently did not have market value and increasing the value of private investments in the surroundings. This was the case of the Vila Autódromo, a favela that was torn down after a long struggle by the residents, to allow the construction of luxury condominiums in a neighborhood that received many investments in urban infrastructure in the context of the Olympic Games (Pimentel 2015). This involves, as Rolnik depicted (2015), a movement of financial capital in search of new fields of accumulation that resulted in an increasingly intense and aggressive process of financialization of housing in the city - not only homes, but of locations and urban equipment and services. (As Rolnik makes clears, this is a national and global process in marginal territories). In this process, housing is no longer treated as a good that can help resolve the "urban question" under a logic of well-being and citizenship (Machado da Silva 2016). As Rolnik affirms, it is a process of "accumulation by dispossession" (Harvey 2005), in which housing is transmuted into a good and a financial asset. In this process, private real estate capital appropriates the valorization produced in these territories and their surroundings by the public investments made there.

In my ethnographies in favelas with UPPs, various residents that I heard criticizing SEBRAE and other agencyings realized and or made viable by the state, complained that practices and legislation were made flexible to effectively promote economic activities and projects conducted by the favela residents: "we raise the data, the potential, make the project, fill in all the forms properly, but we do not get the state financing [via microcredit] because we have no RGI [Registro Geral de Imóveis ${ }^{32}$ [real estate deed], which is required by the state bureaucracy, for the house where the economic or cultural activity would be conducted]."

This difficulty was removed by federal Provisional Measure (MP) 759, enacted on December 22, 2016, which establishes the issuance of deeds for properties in "informal urban nuclei occupied predominantly by low income population". Although it explicitly does not operate with the commodification of these territories, this measure (the first initiative of the federal government in relation to granting deeds to these territories) separates regularization of land ownership from the urbanization of the territories. The measure was received enthusiastically by the leading newspaper $O$ Globo, which is a key supporter of the commodification of the Rio de Janeiro favelas. Citing De Soto (2001), an economist who for decades has defended the regularization of land and the formalization of economic activities in marginal territories, ${ }^{33}$ the newspaper celebrated the "the transformative power of the right to real estate ownership among the poor (...) by means of access to credit [microcredit and entrepreneurship, in this case]. And argues:

\footnotetext{
31 See Birman, Fernandes \& Pierobon (2014).

32 Even if many favelas have been the object of regularization of land ownership, not all the houses have property deeds.

33 "The fact that the formalization of property comes to be a state policy is considered by Peruvian economist Hernando de Soto as essential to triggering a series of social changes. De Soto became known for his solid thesis about the transformative power of the right to real estate ownership among the poor. Like the growth of business, through access to credit, urban improvements, etc., but without the state relinquishing the responsibility to make the needed investments in infrastructure in needy areas." Source: http://oglobo.globo.com/opiniao/o-poder-transformador-do-direito-de-propriedade20703984\#ixzz4UNLJtNsn, accessed December 2016,
} 
[The MP (Provisional Measure) represents] an elastic step in the formalization of microbusinesses, of assistance to an enormous portion of the population - that of low income entrepreneurs, without access to low cost credit, because they do not have anything to offer as a guarantee to the loan provider. They will come to have this. Microcredit and support for training are not new. There are government and private organizations that have been dedicated to this for a long time. Even to assisting the formalization of ownership. But this is the first time that the federal government entered the field in a direct and broad way to get involved in programs to issue property deeds in poor communities. (...) It is necessary to end the illusions about the necessary integration of the poor communities to the formal city. While there is debate, for example, about whether the beneficiary of a program to formalize ownership can sell the property, organized crime infiltrates this ripe clandestine real estate market. (Source: http://oglobo.globo.com/opiniao/o-poder-transformador-do-direito-de-propriedade20703984\#ixzz4UNLJtNsn, accessed in December 2016, emphasis added).

Everything indicates that there is a harmony between the federal, state and municipal governments and a dense articulation between state and market to make the favelas, as well as other peripheries, new territories for business. Residents thus have two options: adhere to this new market dynamics, in which informality constitutes an urbanization strategy, as Roy indicates (2005), or let themselves be driven by the effects of what is known as "disguised evictions" (such as rising housing and living costs, which make it impossible for former residents to remain).

\section{Militarization of life and disciplinarization of residents}

The argument that I have developed sought to demonstrate that the UPPs, as an experiment of governing the poor in carioca favelas, have a dual meaning. It seeks, on one hand, to reconfigure the favelas as new business territories for the market. On the other, it responds to demands for the social and urban integration of the residents, offering them an opportunity for "productive insertion" ${ }^{34}$ through entrepreneurship. This involves substituting state promises and practices (specifically, the scope of public policies for urban and social integration of all Brazilian citizens) for agencyings promoted or mediated by the state "to increase the capacities and opportunities for work and generation of income between the poorest families in the fields and the city". In the case of Rio de Janeiro, the process requires that the residents take advantage of the "window of opportunity" offered by the "pacification" and by the agencyings of the state and its partners, ${ }^{35}$ analyzed above.

It was thus necessary to deal with those demands on the collective plane as well. From this perspective, the strategy of the militarized police forces in various "pacified" favelas has been reducing the social conflicts in the territory, controlling the locally grassroots organizations. And, thus, in the field I observed various situations in which the commander of the local UPP directly intervened in the collective organizations. At the meetings in which he participated and or in the mediations he conducted with the state institutions and the public service utilities, he would redefine the agenda of demands made to the state, through the Social UPP, or the priority of the demands presented, in a clear strategy to shift the "recuperation of the social debt" from the field of citizenship to the repertoire of social projects and entrepreneurship. I also collected many reports of direct interference from the UPP in local resident

\footnotetext{
34 Cf. The Plano Brasil Sem Miséria [Brazil without Misery Plan], launched by the Workers Party government of President Dilma Rouseff, in 2011). \{Hiperlink: www.brasilsemmiseria.gov.br\}, accessed in August 2012, and Leite (2015).

35 "For a successful productive inclusion to occur it is not enough to have good quality opportunities and that they be effectively available to the most poor. It is also essential, that, with their effort and tenacity, poor families take complete advantage of these opportunities.... [that] require protagonism, effort and perseverance....”. Barros et al. (2011: 9). [Ricardo Paes de Barros was then Sub-Secretary for Strategic Actions of the Presidency of the Republic.
} 
associations, whether by steering their activities, or controlling electoral processes, or even in threats to their directors. All of these actions have also been observed and analyzed by other researchers, as portrayed in the articles found in Machado da Silva and Leite $(2014,2015)$.

The residents also complained that daily life in the territory became intolerable with the strict social control of their sociability. The local UPP commander had discretion to decide the hour of the nightly curfew, to determine how informal transportation (motorcycle taxis and vans) could circulate, when funk dances could be held or even parties in private homes and when group events could be organized. The commander was thus referred to as the dono do morro or "boss of the hill", a name traditionally used for leaders of organized crime in the favelas. From this perspective, in the "pacified" favelas, public and private spaces are seen and managed as fields for the production of order, once again in a dual sense. In relation to the streets, yards (for sports or samba), squares and circulation spaces, the logic was to guarantee public order. The UPPs are oriented to impede large gatherings and protests and to repress sociability considered, using a war metaphor, to still be marked by the lifestyle and bonds and loyalties that the state affirms that residents have with the drug dealers. Meanwhile, the administration of private spaces, such as homes, was inserted within a broader logic of establishing discipline over the residents. The control over movement in bars, over people in the streets after 9pm, ${ }^{36}$ of private parties of residents after midnight ${ }^{37}$ reveal the unequivocal sense that the process involves a "pacification" not only of the territory, but also of the residents; of their disciplining.

Under the crisis of Fordism, with the sharp drop in formal employment, and growing unemployment in the Brazilian favelas and peripheries, the residents have been left precarious labor options (temporary, without rights, poorly paid - known in the popular jargon as viração) and entrepreneurship. This process obviously does not involve a disciplinarization of bodies that can be appropriated by capital to be able to extract their greatest utility, as Foucault (2004b) affirmed. My analytical investment is different. The results of my studies indicate that in these territories disciplinary power is operated through another arrangement, in which the administration of populations and territories is conducted under a logic that deepens, in a radical and accelerated manner, a redefinition of how to "make live" (from biopolitics). This thinking no longer follows welfare state concepts, which for a long time capitalist nations considered the ideal way to respond to social problems such as housing. The practices of disciplinarization of the favela residents, under the UPPs, appears to me to no longer have this direction. I suggest that discipline is first an experiment in the normalization of these populations under another logic, which is closer to that which Graham (2009) calls warfare. In Rio de Janeiro, this involves a militarization of the lives of favela residents through the dispositifs of disciplinarization, whose vector is to steer residents to accept the agencyings of productive insertion through entrepreneurship or social projects (particularly the youth). ${ }^{8}$ This is presented as inherent to the times in which we live and something that could be very well taken advantage of by the more diligent and disciplined entrepreneurs, at these time when the market overlaps the state (Gomes 2016).

In collective terms, the disciplinarization is focused on reducing social conflict on two planes. The first, which is immediate and located in the territory to reduce the violence that could spread to other neighborhoods, seeks the dissolution of the real or supposed ties of the residents of the "pacified" favelas with networks of illicit activities. The second is broader and has the potential to be replicated in other territories and populations. It seeks to reposition their demands in the field of citizenship rights to the field of consumption and entrepreneurship, or to simply silence them. To this is added the militarization of life

36 For an analysis of this mode of territorial management in the favela of Borel and of the reactions of the residents through the "Ocupa Borel", see Leite (2013).

37 The same control is not exercised in relation to the events organized by business leaders/and people from outside".

38 For an analysis of the mode of territorial management in São Paulo, see Rizek (2012). 
in these favelas and the suffocation of the agency of their residents, which is the other repressive face of the attempt to produce a consensus by offering productive inclusion through entrepreneurship and social projects. As I analyzed in other studies, these practices of normalization involved in the militarization of life in the "pacified" favelas are one of the faces ${ }^{39}$ of the "civilizing pedagogy", whose sense is to allow

the production of the favelado as a civilized and territorialized "new man" (as a type of aggiornamento of Fordism, of course in conditions that are quite different from the original process). A new actor that is interpellated by those "from the outside", through state and non-governmental initiatives, through various policies and projects (training courses, participation in various forums and special lines of credit for the development of entrepreneurship in "pacified" favelas, among others) to become a small business owner, cultural producer/ impresario of activities in the territory for example. Informal work is transmuted into self-employment, given increased value by initiative and autonomy, raising the mark of the favela as a now positive distinction in the market. To transform the favelado, (favela resident), to produce this new man, first "pacified" (or that is, separated from the ties to the illegal drug trafficking networks and the accompanying violence), later captured by the market (through the ideology of entrepreneurship that animates the state and non-governmental initiatives in the territory) thus appears to be the imperative strategic matrix, in Foucault's terms, of the [current] dispositifs of alteration of the place of "margin" of the favelas in the city (Leite 2015: 397-398).

Arguing that this process of commodification of the "pacified" territories continues underway despite the "crisis of the UPPs", I would like to briefly comment on the field of possibilities that are opened to the residents who do not adjust to these agencyings and to this "civilizing pedagogy". In relation to the commodification of the territory, few alternatives are left for them, including their expulsion from their residential territories by market forces such as rising prices as discussed in the previous section. In the specific field of violence and public safety, a dispositif of the sovereign power remains available to the militarized forces, which is updated in these territories under the logic of the metaphor of war: the power to "let die" applied to those considered to be ungovernable or unable to be disciplined because of their real or supposed connection with violent crime (Leite 2012; Farias 2014; Araújo 2012). As Oliveira (2014) affirms, reconsidering colonial experiences with the management of territories and populations to analyze the Rio de Janeiro UPPs, "pacification" was always an administrative category, of a military-police nature, through which, under the mantle of a "civilizing mission" the route is opened to the operation of dispositifs of guardianship, coercion and elimination of the agency of the wards, or even - at the extreme - of their bodies, through colonial genocide.

To conclude this section, I would like to emphasize two points. First, the administration of territories and populations under the UPPs constitutes a modality of governing of the poor that involves a territorially inscribed articulation (which I have been seeking to describe analytically based on the notion of "territorial regime") of different powers - the sovereign, the disciplinary and biopower (Foucault 2004a, 2008). Collier (2009) suggests grasping this articulation as "topologies of power": specific arrangements of dispositifs of governmentality that recombine different elements - technologies of security, institutional structures and material forms of these powers, conferring them a new meaning ${ }^{40}$. Second, the territorial inscription of these powers is not conducted homogenously in the "pacified" favelas. In other words, my hypothesis is that through this experiment with the UPPs, various territorial regimes have been established in

39 Another face are the agencyings aimed at children, an object of specific investment of the UPPs and of the NGOs because they have still not been "lost to crime".

40 See, for an example, Birman \& Machado (2012) for the constitution of symbolic and territorial circuits in which criminality and religion are intertwined. 
these locations, given that each one of them absorbs in a specific way (through various adjustments, negotiations, resistances and confrontations, which relate to the situational and temporal configurations) the new dispositifs of government of the poor, in an active coproduction of territory as margin and of the state itself. ${ }^{41}$

\section{From the local to the national, passing through the transnational circuits to govern the poor}

I conclude this article with the suggestion that the dynamics that we have examined locally are not exclusive to Rio de Janeiro. Experienced in the city, they have been replicated (with adjustments and new arrangements in terms of the technologies of safety, according to the specific objectives to be attained) in other territories and situations, and in relation to the populations that are to be disciplined. In this case, the most eloquent example is the militarization of public schools frequented by low income youth in various Brazilian cities, through partnerships between the local secretariats of education and public safety. As Carneiro and Sant'Anna (to be published) analyze, by assuming the administration of these schools, the military forces, more than fighting the violence in the school universe or their surroundings, promote a policing of the conduct of students with a systematic recourse to dispositifs for discipline and "exception" inspired by the militarization of territories under UPPS.

Many analytical leads, that unfortunately I cannot follow within the space of this article, indicate the productivity of considering how to experiment with this new mode of security government in various Brazilian cities (frequently with financing from private companies and consulting from multilateral agencies), especially in relation to population segments that, because of their way of life and or agencying, in some way challenge and confront the established social order. For example, the militarization of the management of urban conflicts against the commodification of life and for the right to the city (Saborio 2015, Cardoso 2013), and in relation to people living in the streets (Rui 2012, to be published) and in occupied structures (Fernandes 2013). They also indicate how much the UPP experiment benefitted from other experiences of management of urban space, such as "Operação Saturação" [Saturation Operation] $]^{42}$. Hirata (2015) demonstrates these connections by analyzing how "Operação Delegada" [Delegated Operation, a partnership between the municipal and state governments of São Paulo], which was begun in São Paulo in 2009, and the "Units of Public Order", created in Rio de Janeiro in 2011, produced a militarization of the dispositifs for controlling street merchants that involved twists in legality in the name of "guaranteeing public order" and a close articulation between political markets and illegal markets.

Specifically concerning the living territories of the poor, it is worth emphasizing that there have been many suggestions and requests to replicate the UPP experiment in other Brazilian and Latin American cities. This indicates the analytical validity of examining this production of order. From the parliamentary initiative to nationalize the UPPs, to the demands of residents and governments from other cities for their local implementation to their diffusion in international circuits by think tanks from the field of "citizen security", everything indicates that this experiment in the production of order through militarization of life and territory has been raised to the category of a "good practice" for the government of cities and urban safety and will persist in the field of possible solutions for some time.

41 I refer readers to the various situations described and analyzed in the bibliography mentioned that focuses on the UPPs.

42 Military occupation, from 2005 to 2010, in the favela of Paraisópolis, located close to an elite neighborhood of São Paulo, which was followed by 14 interventions in other locations (Matiolli and Magalhães $\mathrm{s} / \mathrm{d}$ ). 
We live today in a moment of capitalism in which state and market are articulated in the search for new forms of dealing with social conflicts that can no longer be resolved by promises of citizenship, or by public, urban and social policies, which are made horizontal and universal, and by the resolution of the housing issue (Oliveira 2003, Machado da Silva 2002). This is also a time in which the militarization of life, of the living territories of the poor, as well as the redefinition of work, the reduction of conflicts and the selective incorporation of some (productive inclusion via entrepreneurship) are experiments that have been tested in our cities to simultaneously produce order and adjust it to the "imperatives of the market". Machado da Silva, in various personal communications, has been referring to this process as an inversion of the politicalization of the market analyzed by Polanyi (1980). In this understanding, we are living in a context in which the market has captured politics, submitting it to its dictates and needs (and the production of order would continue and would implement this direction).

In another register, it appears to me that these experiments in the production of order in Rio de Janeiro favelas reveal one of the current faces of governmentalization of the state (Foucault 2010) and allow us to expand our understanding of this form of government in these territories. In other words, by shifting our analyses from the strict plane of state action and its institutional structure and specific forms of regulation, and by moving away from a rigid definition of what is traditionally defined as public and private, perhaps we can better understand in situ, who has been exercising power and governing territories and populations and how, the arrangements of power used, the dispositifs mobilized and the agencyings realized. ${ }^{43}$

* I presented some versions of this text at the research workshop "Ressonâncias da produção da cidade contemporânea no Rio e em São Paulo" organized by Vera Telles, at the Universidade de São Paulo, and at the 2 o Seminário Cidades, Espaços Públicos e Periferias, at the Universidade Federal Fluminense/Campos, both in 2016. I would like to thank Vera Telles, Machado da Silva, Daniel Hirata, Lívia de Tommazi and Jussara Freire for their productive comments and criticisms and Fransérgio Goulart and Rodrigo Calvet for the interlocution, which has provided me important analytical leads. I also tank to my friends and partners, Juliana Farias, Carly Machado, Patricia Birman, Ramon Gomes, Lia Rocha, Edson Miagusko, Cibele Rizek, for all.

Translated by: Jeffrey Hoff

Received: December 31, 2016; Approved: August 01, 2017

43 As Davies does (2017) analyzing the forms of government in a neighborhood of the city marked by a traditional occupation and military administration in the territory, and how their revision combines dispositifs and agencyings of the state and market in the context that we analyzed. 


\section{References}

ARAÚJO, Fábio. 2012. Das consequências da "arte" macabra de fazer desaparecer corpos: violência, sofrimento e política entre familiares de vítima de desaparecimento forçado. Tese de doutorado, Programa de PósGraduação em Antropologia e Sociologia da Universidade Federal do Rio de Janeiro - Rio de Janeiro. AZEVEDO, Lena; FAULHABER, Lucas. 2015. Remoções no Rio de Janeiro Olímpico. Rio de Janeiro: Mórula Editorial.

BARROS, Ricardo Paes de et al. 2011. "Portas de erradicação da extrema pobreza", disponível em www.sae. gov.br/site/wp-content/uploads/.pdf, acesso em agosto 2012.

BESSEN, Daphne. 2016. A estratégia municipal de internacionalização da Cidade do Rio de Janeiro de 2009 a 2016: Rio, uma cidade global? Dissertação de Mestrado, Programa de Pós-Graduação em Ciências Sociais, Universidade do Estado do Rio de Janeiro - Rio de Janeiro.

BIRMAN, Patricia; FERNANDES, Adriana; PIEROBON, Camila. 2014. "Um emaranhado de casos: tráfico de drogas, Estado e precariedade em moradias populares", Mana, 20(3): 431-46o.

; MACHADO, Carly. 2012. "A violência dos justos: evangélicos, mídia e periferias da metrópole", Revista Brasileira de Ciências Sociais, 27(80): 55-69.

CANO, Ignacio et al. 2012. (org.). "'Os donos do morro': uma avaliação exploratória do impacto das Unidades de Polícia Pacificadora (UPPs) no Rio de Janeiro”. Rio de Janeiro: Fundação Heinrich Böll/LAV-UERJ.

CARDOSO, Adalberto. 2013. "As jornadas de junho e a mercantilização da vida coletiva". Insight-Inteligência, 15(66): 23-30.

CARNEIRO, Sandra; SANTANA, Maria Josefina. No prelo. "Militarização de escolas públicas: repercussões sobre este novo modelo de gestão escolar". In: M. Leite et al. (org.), A militarização da vida urbana. Rio de Janeiro: Mórula Editorial.

CARVALHO, Monique Batista. 2014. Os dilemas da "pacificação": práticas de controle e disciplinarização na "gestão da paz" em uma favela do Rio de Janeiro. Tese de Doutorado, Programa de Pós-Graduação em Ciências Sociais, Universidade do Estado do Rio de Janeiro - Rio de Janeiro.

COLLIER, Sthepen. 2009. “Topologies of power: Foucault's analysis of political government beyond 'governmentality"'. Theory, Culture \& Society, 26(6): 78-108.

COMPANS, Rose. 1999. “O paradigma das global cities na estratégia de desenvolvimento local”. Revista Brasileira de Estudos Urbanos e Regionais, 1: 91-114.

CONCEIÇÃO, Wellington da Silva. 2016. Minha casa, suas regras, meus projetos. Gestão, disciplina e resistências nos condomínios populares do PAC e do PMCMV no Rio de Janeiro. Tese de Doutorado, Programa de PósGraduação em Ciências Sociais, Universidade do Estado do Rio de Janeiro - Rio de Janeiro.

CUNHA, Neiva Vieira; MELLO, Marco Antonio da Silva. 2011. "Novos conflitos na cidade: o processo de urbanização na favela”. Dilemas - Revista de Estudos de Conflito e Controle Social, 4(3): 371-401.

DAS, Veena; POOLE, Deborah. 2004 (org.), Anthropology in the margins of the State. Oxford: James Currey.

DAVIES, Frank Andrew. 2017. "Deodoro: formas de governo para uma 'região olímpica". Tese de doutorado em Ciências Sociais. Sociologia, Programa de Pós-Graduação em Ciências Sociais da Universidade do Estado do Rio de Janeiro - Rio de Janeiro.

DE SOTO, Hernando. 2001. O mistério do capital. Rio de Janeiro: Record.

DE TOMMAZI, Lívia. No Prelo. "Empreendedores da cultura: jovens produtores culturais de favela entre trabalho, ativismo e criatividade”. In: M. Leite et al. (org.), A militarização da vida urbana. Rio de Janeiro: Mórula Editorial.

ESPÍNDOLA, Gislaine Gomes. 2009. Da cidade que se tem à cidade que se quer: "Ilegal. E daí?” e a CPI da Desordem Urbana. Monografia de Conclusão da Especialização em Sociologia Urbana, Instituto de Ciências Sociais da Universidade do Estado do Rio de Janeiro - Rio de Janeiro. 
FARIAS, Juliana. 2014. Governo de mortes. Uma etnografia da gestão de populações de favelas no Rio de Janeiro. Tese de doutorado em Sociologia, Programa de Pós-Graduação em Antropologia e Sociologia da Universidade Federal do Rio de Janeiro - Rio de Janeiro.

FERGUSON, James; GUPTA, Akhil. 2002. "Spatializing States: toward an ethnography of neoliberal governmentality”. American Ethnologist, (29)4: 981-1002.

FERNANDES, Adriana dos Santos. 2013. Escuta Ocupação: arte do contornamento, viração e precariedade no Rio de Janeiro. Tese de Doutorado. Programa de Pós-Graduação em Ciências Sociais da Universidade do Estado do Rio de Janeiro - Rio de Janeiro.

FREIRE, Jussara. 2016. Problemas públicos e mobilizações coletivas em Nova Iguaçu. Rio de Janeiro: Garamond/ FAPERJ.

FREIRE-MEDEIROS, Bianca. 2013. Tourism poverty. Nova York: Routleledge.

FOUCAULT, Michel. 2004a. Securité, territoire, population. Paris: Gallimard/Seuil. . 2004b. Vigiar e punir. Nascimento da prisão. Petrópolis: Vozes. 2008. Nascimiento de la biopolítica. Buenos Aires: Fondo de Cultura Económica. 2010. Ditos e escritos IV. 2a ed. Rio de Janeiro: Forense Universitária.

GOMES, Ramon Chaves. 2016. Gestão da sobrevivência e empreendedorismo como projeto. O 'problema favela' no regime de acumulação financeira. Monografia de conclusão do Bacharelado em Ciências Sociais da Universidade do Estado do Rio de Janeiro - Rio de Janeiro.

GRAHAM, Steve. 2009. "The urban 'battlespace". Theory, Culture \& Society, 26(7-8): 278-288.

HARVEY, David. 2005. A produção capitalista do espaço. São Paulo: Anablume.

HIRATA, Daniel. 2015. “Comércio ambulante no Rio de Janeiro e em São Paulo: grupos de poder e instrumentos contemporâneos de governo". In: P. Birman et al. (org.), Dispositivos urbanos e trama dos viventes: ordens e resistências. Rio de Janeiro: FGV. pp. 95-120.

LEITE, Márcia Pereira. 2012. "Da 'metáfora da guerra' ao projeto de 'pacificação': favelas e políticas de segurança pública no Rio de Janeiro". Revista Brasileira de Segurança Pública, (6)2: 374-389.

_-_. 2013. "Território e ocupação: afinal de que regime se trata?". Le Monde Diplomatique Brasil, 6(67): 13.

--_- 2015. "De territórios de pobreza a territórios de negócios: dispositivos de gestão das favelas em contexto de 'pacificação"'. In: P. Birman et al. (org.), Dispositivos urbanos e trama dos viventes: ordens e resistências. Rio de Janeiro: FGV. pp. 377-401.

LIMA, José Luiz de S. 2008. Empreendedorismo social: uma perspectiva de cidadania social e alternativa de trabalho e renda nos espaços populares. Dissertação de Mestrado, Programa de Pós-Graduação em Ciências Sociais, Pontifícia Universidade Católica do Rio de Janeiro - Rio de Janeiro.

LORETTI, Pricila. 2016. Energias da crítica: o conflito entre moradores da Favela Santa Marta, Rio de Janeiro, em contexto de "pacificação". Tese de Doutorado, Programa de Pós-Graduação em Ciências Sociais, Universidade do Estado do Rio de Janeiro - Rio de Janeiro.

MACHADO DA SILVA, Luiz Antonio. 2002. "Da informalidade à empregabilidade: reorganizando a dominação no mundo do trabalho". Cadernos CRH, 37: 81-109. . 2016. "Meio século de sociologia das classes populares urbanas". In: Fazendo a cidade: trabalho, moradia e vida local entre as camadas populares urbanas. Rio de Janeiro: Mórula Editorial. pp. 15-32. . 2008. (org.). Vida sob cerco: violência e rotina nas favelas do Rio de Janeiro. Rio de Janeiro: Nova Fronteira. ; LEITE, M. P. 2014. (org.). "Dossiê Unidades de Polícia Pacificadora”. Dilemas: Revista de Estudos de Conflito e Controle Social, 7(4): 607-702.

; LEITE, M. P. 2015. (org.). “Dossiê Unidades de Polícia Pacificadora”. Dilemas: Revista de Estudos de Conflito e Controle Social, 8(1): 7-96. 
MAGALHÃES, Alexandre. 2013. “O 'legado’ dos megaeventos esportivos: a reatualização da remoção de favelas no Rio de Janeiro". Horizontes Antropológicos, 19(40): 89-118.

MATIOLLI, Thiago; MAGALHÃES, Taís. s/d. "Segurança e controle social no Rio de Janeiro e em São Paulo: as Unidades de Polícia Pacificadora e a Operação Saturação”, disponível em http://actacientifica. servicioit.cl/biblioteca/gt/GT4/GT4_MatiolliTMagalhaesT.pdf, acesso em dezembro de 2016.

MENEZES, Palloma. 2015. Entre o 'fogo cruzado' e o 'campo minado': uma etnografia do processo de pacificação de favelas cariocas. Tese de Doutorado. Programa de Pós-Graduação em Sociologia do Instituto de Estudos Sociais e Políticos da Universidade do Estado do Rio de Janeiro - Rio de Janeiro.

MEZA, Ricardo Vargas. 2015. "Narcotráfico, conflito armado e segurança: uma perspectiva a partir do caso colombiano”. In: A. Peralva e V. Telles (orgs.), Ilegalismos na globalização: migrações, trabalho, mercados. Rio de Janeiro: Editora da UFRJ. pp. 355-381.

MIAGUSKO, Edson. 2012. "Antes da Copa, depois do Pan: o Rio de Janeiro na era dos megaeventos esportivos". Civitas, 12(2): 395-408.

MIAGUSKO, Edson. 2016. "Esperando a UPP: Circulação, violência e mercado político na Baixada Fluminense”. Revista Brasileira de Ciências Sociais, 31(91), e319101, disponível em http://www.scielo.br/ scielo.php?script=sci_arttext\&pid=So102-69092016000200501\&lng=pt\&nrm=iso, acesso em setembro de 2016.

MISSE, Michel. 2011. Crime e violência no Brasil contemporâneo: estudos de sociologia do crime e da violência urbana. Rio de Janeiro: Lumen Juris.

OLIVEIRA, Francisco de. 2003. Crítica à razão dualista/O ornitorrinco. São Paulo: Boitempo Editorial.

OLIVEIRA, João Pacheco de. 2014. "Pacificação e tutela militar na gestão de territórios e populações". Mana. Estudos de Antropologia Social, 20(1): 125-161.

OST, Sabrina; FLEURY, Sonia. 2013. "O mercado sobe o morro. A cidadania desce? Efeitos socioeconômicos da pacificação no Santa Marta”. DADOS - Revista de Ciências Sociais, 56(3): 635-671.

PALERMO, Luís Cláudio. 2011. O discurso da imprensa sobre a instalação das unidades de polícia pacificadora: representações sobre as favelas cariocas. Monografia de Conclusão da Especialização em Sociologia Urbana da Universidade do Estado do Rio de Janeiro - Rio de Janeiro.

PIMENTEL, Ana Cristina. 2015. "Vila Autódromo: uma comunidade pacífica e ordeira desde 1967" - a construção da remoção como um problema público. Tese de Doutorado, Programa de Pós-Graduação em Ciências Sociais, Universidade do Estado do Rio de Janeiro - Rio de Janeiro.

POLANYI, Karl. 1980. A grande transformação: as origens de nossa época. Rio de Janeiro: Campus.

RIBEIRO, Luiz Cesar de Queiroz; SANTOS Jr., Orlando. 2013. "Governança empreendedorista e megaeventos esportivos: reflexões em torno da experiência brasileira". O Social em Questão, 29: 23-42.

RIZEK, Cibele. 2012. Trabalho, moradia e cidade. Zonas de indiferenciação? Revista Brasileira de Ciências Sociais, $27(78):$ 41-49.

ROCHA, Lia de Mattos. 2013. Uma favela "diferente das outras"? Rotina, silenciamento e ação coletiva na Favela do Pereirão. Rio de Janeiro: Quartet/ FAPERJ.

ROCHA, Lia de Mattos. 2014. “Da 'cidade integrada' ao 'empreendedorismo': participação e gestão nas margens em tempos de 'pacificação"'. Trabalho apresentado no GT Sobre Periferias: novos conflitos no espaço público. 38a ANPOCS, Caxambu, MG. Mimeo.

ROLNIK, Raquel. 2015. Guerra dos lugares. A colonização da terra e da moradia na era das finanças. São Paulo: Boitempo Editorial.

ROY, Ananya. 2012. "Ethnographic circulations - space-time relations in the worlds of poverty management". Environment and Planning, 44: 31-41. 
2005. "Urban informality: toward an epistemology of planning". Journal of American Planning Association, 71(2): 147-158.

RUI, Taniele. No prelo. "Da deriva pela Av. Brasil à fixação numa esquina na Maré: usuários de crack, refugiados da 'pacificação' In: M. Leite et al. (org.), A militarização da vida urbana. Rio de Janeiro: Mórula Editorial.

. 2012. Corpos abjetos: etnografia em cenários de uso e comércio de crack. Tese de doutorado. Universidade Estadual de Campinas - Campinas.

SABORIO, Sebastian. 2015. "The new military urbanism: police repression and conflict in Rio de Janeiro". Trabalho apresentado em seminário do Cidades: Núcleo de Pesquisa Urbana, Universidade do Rio de Janeiro - Rio de Janeiro. Mimeo.

TELLES, Vera da Silva; CABANES, Robert. 2006. (orgs.). Nas tramas da cidade: trajetórias urbanas e seus personagens. São Paulo: Humanitas.

VALLADARES, Lícia. 2005. A invenção da favela. Rio de Janeiro: FGV.

Márcia Pereira Leite

CNPq Researcher

Rio da Janeiro State University, Institute of the Social Sciences, Rio de Janeiro/RJ, Brazil.

Rua Presidente Carlos de Campos, n. 13/201 - Laranjeiras, Rio de Janeiro/RJ. CEP 22231-o8o.

E-mail: marciadasilvapereiraleite@gmail.com 